\title{
USE OF BIOLOGICAL AGENTS FOR DISEASE MANAGEMENT OF TOMATO IN BHAKTAPUR OF NEPAL
}

\author{
P.R. Adhikari ${ }^{1}$, S. Baral ${ }^{2}$ and B. Bhandari ${ }^{3}$
}

\begin{abstract}
The experiment was conducted in tomato crop grown under plastic house in farmers' field condition in two VDCs of Bhaktapur District in two seasons in 2011/2012. The objective of the studies was to train the IPM facilitators for the production and multiplication of bio-control agents (Trichoderma harzianum, Trichoderma viride and Pseudomons fluorescens ), to advocate the benefit of bio-control method for protection of crops and reduce the use of chemical pesticides in vegetables and to taste the efficacy of commercially available bio-pesticides. Trichoderma viride, T.harzianum, Pseudomons fluorescens and Bavistin were applied in seed and seedlings treatment, and foliar spray. The result revealed that seed and seedlings treated with $\mathrm{T}$. species and Pseudomons fluorescens were healthier than those treated with chemical fungicides and produced higher yield.
\end{abstract}

Key Words: Biological agents, bio-pesticides, disease management, tomato

\section{INTRODUCTION}

Tomato is an important crop for income generation of urban and rural farmers of Nepal but they are facing some problems of insects and diseases. Among them damping off, late blight, mosaic virus, nematode in disease and aphid, white flies, leaf minor and fruit borer insects are major problems in mountain and mid hills of Nepal in tomato. Damping off is common occurrence in nursery beds and young seedlings resulting in reduced seed germination and poor stand. Late blight, caused by Phytophthora infestans fungus is one of the destructive diseases in tomato and potato where $20-90 \%$ losses occurr annually. The fungus can attack on leaves, stems and tubers of potato and leaves, stems and fruits in tomato. Host resistance with fungicide application, chemicals, biological and integrated disease management can control the disease.

Forcelini et al.(2001) and Deising et al. (2008) focused on increasing use of chemicals has become an issue on alarming increase in fungicide resistance of plant pathogens in number of crops in modern agricultural practices in several countries. Biological control methods involving the use of natural antagonist of pathogens and predators, parasitoids and parasites have been suggested a safe alternative of chemical method of disease and insect control.

Depending upon the host variety and environmental factors, $25-75 \%$ losses are caused annually by damping off. The fungus have a wide range of crops to attack under the

\footnotetext{
${ }^{1}$ Senior Plant Protection Officer, Ministry of Agricultural Development, Nepal

${ }^{2}$ Senior Apiculturist, Beekeeping Development Section, Department of Agriculture

${ }^{3}$ Agronomist, Nepal Agricultural Research Council, Corresponding Email:parashu.adhikari@gmail.com 
families Solanaceae, Crucifereae, Leguminosae and Chenopodiceae. A numbers of fungi like Pythium, Phytophthora, Rhizoctonia and Fusarium are most common and Alternaria,Botrytis, Phoma, Sclerotinia, Sclerotium, Aphanomyces, Pyrenochaeeta, Ozonium Glomorella etc. can also cause damping off (Gupta and Paul,2001).

Several fungi, bacteria, virus and nematodes that attacks plants and cause several billion rupees worth of agricultural losses each year in Nepal. Some chemicals used to control these diseases may also contribute to environmental contamination and toxicity to animals and human. Nowadays, some biological agents are applied and found effective for disease and insect management. Beneficial fungi and bacteria those have potential to suppress soil borne diseases specially damping off, wilts, Phytophthora, and Pythium are available in the market.

Cultural practices, biological control, chemicals and integrated disease management can reduce the incidence and intensity of different kinds of diseases in crops. But we should consider the impact of the used chemicals on animals and human health, effect on environment, cost effectiveness as well as sustainability in production.

\section{METHODOLOGY}

The tomato seed was treated by Trichoderma viride, T. harzianum, Pseudomonas fluorescens @ $5 \mathrm{~g} / \mathrm{kg}$ and Bavistin@ $2 \mathrm{~g} / \mathrm{kg}$ seed half an hour before sowing in each one meter square area of replicated nursery plots on Chaitra 12, 2067. Observation of the germination and disease status was conducted in seven days interval until transplanting.

The seedlings ( 20 numbers) were treated by the same bio-fungicides ie@10g/liter of water and Bavistin@5g/liter of water, before planting in all the plots in $45 \times 60 \mathrm{~cm}$ spacing under the plastic house. Same cultural practices were used in all treatments. Late blight and other foliar diseases were observed in both locations and all biological and chemical fungicides were sprayed 3 times in 15 days interval.. Dalila variety of tomato was sown in Bageswori and Shrijana was sown in Sudal VDC in spring and summer season. Economic analysis was done by comparing biological and chemical fungicides. Number of damping off affected seedlings and healthy seedlings were recorded in nursery bed and calculation was done as follows:

Damping off $(\%)=$ Damping of seedlings $\times 100 /$ Number of total seed planted Healthy seedlings $(\%)=$ Total seedlings - Damping off seedlings

For the sustainability of the disease and insect management methods in farmer's level, disease scoring, simple statistical test i.e. overlap test in case of yield, benefit-cost ratio, and Duncan's multiple range test (DMRT) were applied during the analysis. 


\section{RESULT AND DISCUSSION}

EFFECT OF TREATMENTON DAMPING OFF AND HEALTHY SEEDLINGS

Tomato seedlings were observed and counted after germination. Some seeds could not germinate due to its low viability and disease attack before the emergence from ground level and some died after emergence which is called damping off disease. Healthy seedlings having vigorous, dense and long roots were counted while transplanting in the main field and found following results.

Table-1: Influence of bio and chemical fungicides applied in seed treatment on Dalila variety of tomato against damping off in nursery bed at Bhaktapur district.

\begin{tabular}{|l|l|l|l|l|}
\hline \multirow{2}{*}{ Treatments } & \multicolumn{2}{|c|}{ Spring Season } & \multicolumn{2}{c|}{ Summer Season } \\
\cline { 2 - 5 } & $\begin{array}{c}\text { Damping } \\
\text { off affected } \\
\text { plants (\%) }\end{array}$ & $\begin{array}{c}\text { Survived plants at } \\
\text { transplanting (\%) }\end{array}$ & $\begin{array}{c}\text { Damping off } \\
\text { affected } \\
\text { plants(\%) }\end{array}$ & $\begin{array}{c}\text { Survived plants at } \\
\text { transplanting (\%) }\end{array}$ \\
\hline T. viride & 10 & 90 & 12 & 88 \\
\hline $\begin{array}{l}\text { T. } \\
\text { harzianum }\end{array}$ & 12.5 & 87.5 & 14.5 & 85.5 \\
\hline $\begin{array}{l}\text { P. } \\
\text { fluorescens }\end{array}$ & 13.5 & 86.5 & 13.5 & 86.5 \\
\hline Bavistin & 21.25 & 78.75 & 25.0 & 75.0 \\
\hline Control & 30 & 70 & 37 & 63 \\
\hline CV \% & 88.45 & 8.22 & 57.55 & 21.43 \\
\hline
\end{tabular}

Survived and healthy seedlings of tomato were found in higher percentage in both season crop in the plot treated by $\mathrm{T}$. viride $(90 \%$ and $88 \%)$ and T. harzianum $(87.5 \%$ and $85.5 \%)$ followed by Pseudomonas fluorescens ( $87.5 \%$ and $85.5 \%)$. Whereas chemical fungicide used plots have less healthy seedlings $(78.75 \%$ and $75.0 \%)$ as compared to bio agents used plots in both seasons.

The occurrence of damping off disease and healthy seedlings in tomato nursery in Shrijana variety on spring and summer season was found as follows- 
Table2. Influence of bio and chemical fungicides applied in seed treatment on Shrijana variety of tomato against damping off in nursery bed at Bhaktapur district

\begin{tabular}{|l|l|l|l|l|}
\hline \multirow{2}{*}{ Treatments } & \multicolumn{2}{|c|}{ Spring Season } & \multicolumn{2}{c|}{ Summer Season } \\
\cline { 2 - 5 } & $\begin{array}{c}\text { Damping off } \\
\text { (\%) }\end{array}$ & $\begin{array}{l}\text { Survival plant at } \\
\text { transplanting (\%) }\end{array}$ & $\begin{array}{c}\text { Damping off } \\
\text { (\%) }\end{array}$ & $\begin{array}{l}\text { Survival plant at } \\
\text { transplanting (\%) }\end{array}$ \\
\hline T. viride & 22.62 & 87.38 & 15 & 85 \\
\hline T. harzianum & 15.48 & 84.52 & 20 & 80 \\
\hline P.fluorescens & 12.98 & 87.02 & 18 & 82 \\
\hline Bavistin & 34.29 & 65.71 & 33 & 67 \\
\hline Control & 41.52 & 58.48 & 44 & 56 \\
\hline CV \% & 23.44 & 23.44 & 6.43 & 25.53 \\
\hline
\end{tabular}

We found, there is no significant difference in healthy seedlings of the tomato among Trichoderma and Pseudononas fluorescens treated plots in both seasons. But the significant difference in healthy seedlings were found less in Bavistin treated plots in spring $(65.71 \%)$ and summer season (67\%) as compare to Trichoderma and Pseudononas fluorescens treated plots. Similar results were found by the control plot also.

The attack of damping off disease in tomato found more in summer season as compared to spring season due to favorable temperature, humidity and environment and not proper work while applied bio agents or chemical fungicide. Therefore, we should practice other integrated approaches to reduce the incidence of damping off. Integrated approaches includes choose the nursery in sunny place, add manure to raise soil fertility and aeration, sown the seeds with wider spacing, raise the soil and provide proper drainage. Sharma (2011) found that the application of bio-agents in controlling Fusarium infection of seeds can cause $100 \%$ germination and $90 \%$ control of disease.

EFFECT OF TREATMENT ON ROOT LENGTH AND NUMBER OF LEAVES AT TRANSPLANTING Bio-agents while used in disease control produce enzymes and antibiotics to defence the pathogen. Then plant can observed more food from its rhizosphare which results plant vigor, long and more fiber roots and more number of leaves. Root length and number of leaves at transplanting were observed and recorded as follows.

Table 3. Influence of bio and chemical fungicides in root length and number of leaves at transplanting of Shrijana tomato applied in seed treatment

\begin{tabular}{|l|l|l|l|l|}
\hline \multirow{2}{*}{ Treatments } & \multicolumn{2}{|c|}{ Spring season } & \multicolumn{2}{c|}{ Summer Season } \\
\cline { 2 - 5 } & Root length $(\mathbf{c m})$ & Leaves $($ No) & Root length $(\mathbf{c m})$ & Leaves (No) \\
\hline T. viride & 2.5 & 6 & 3.5 & 6 \\
\hline T. harzianum & 3.5 & 7 & 3.7 & 6 \\
\hline P.fluorescens & 2.5 & 7 & 2.9 & 7 \\
\hline Bavistin & 1.5 & 6 & 1.8 & 6 \\
\hline Control & 1.3 & 5 & 1.5 & 5 \\
\hline CV & 24.28 & 6.75 & 18.61 & 19.63 \\
\hline
\end{tabular}


The root length of tomato at transplanting was found higher $(3.5$ and $3.7 \mathrm{~cm}$ ) in Trichoderma harzianum followed by $T$. viride $(2.5 \mathrm{~cm}$ and $3.5 \mathrm{~cm})$ in both seasons. Root length of seedlings in Bevistin applied plots found less $(1.5 \mathrm{~cm}$ and $1.8 \mathrm{~cm})$ as compare to other bio-fungicides. The lowest root length $(1.3 \& 1.5 \mathrm{~cm}$ ) and number of leaves $(5 \& 5)$ were found in control plots in both seasons.

The root length in both varieties found higher in summer crop than the spring due to hardiness of soil structure during same duration. But the number of leaves found no significant different in variety and seasons. The root length and number of leaves at transplanting of Shrijana variety in two seasons are as follows.

Table 4. Influence of bio and chemical fungicides in root length and number of leaves of Dalila tomato at transplanting

\begin{tabular}{|l|l|l|l|l|}
\hline \multirow{2}{*}{ Treatments } & \multicolumn{2}{|c|}{ Spring season } & \multicolumn{2}{c|}{ Summer Season } \\
\cline { 2 - 5 } & Root length $(\mathrm{cm})$ & Leaves (No) & Root length $(\mathrm{cm})$ & Leaves (No) \\
\hline T. viride & 4.3 & 5.2 & 4.5 & 6 \\
\hline T. harzianum & 5 & 4.8 & 5.3 & 7 \\
\hline P.fluorescens & 4 & 7 & 4.2 & 7.5 \\
\hline Bavistin & 3.7 & 4 & 3.9 & 5 \\
\hline Control & 3 & 3.9 & 3.4 & 5 \\
\hline CV & 9.23 & 12.59 & 8.32 & 9.22 \\
\hline
\end{tabular}

The root length of seedlings were found higher in T. harzianum $(5.0$ and $5.3 \mathrm{~cm}$ ) treated plots in both seasons followed by T. viride $(4.3$ and $4.5 \mathrm{~cm})$. Molecules produced by Trichoderma and / or its metabolic activities also have potential for promoting plant growth (Yadidia et al., 1999). Bavistin treated plots were found shorter root lengh (3.7 and $3.9 \mathrm{~cm})$ as compare to Pseudomonas fluorescens $(4.0$ and $4.2 \mathrm{~cm})$ and Trichoderma treated plots. There is significant difference in root length in Bevistin treated and control plot.

\section{EFFECT OF TREATMENT ON AREA COVERAGE BY THE PLANT}

Bio-agents besides antagonist and mycoparasitism characteristics, they have potential character to increase seed germination percentage, root and shoot length, fresh weight and dry weight in many plants. These results have seen in the trial tomato also. More area was covered by bio-control agents treated plant as compare to chemical fungicide treat (Figure 1). 

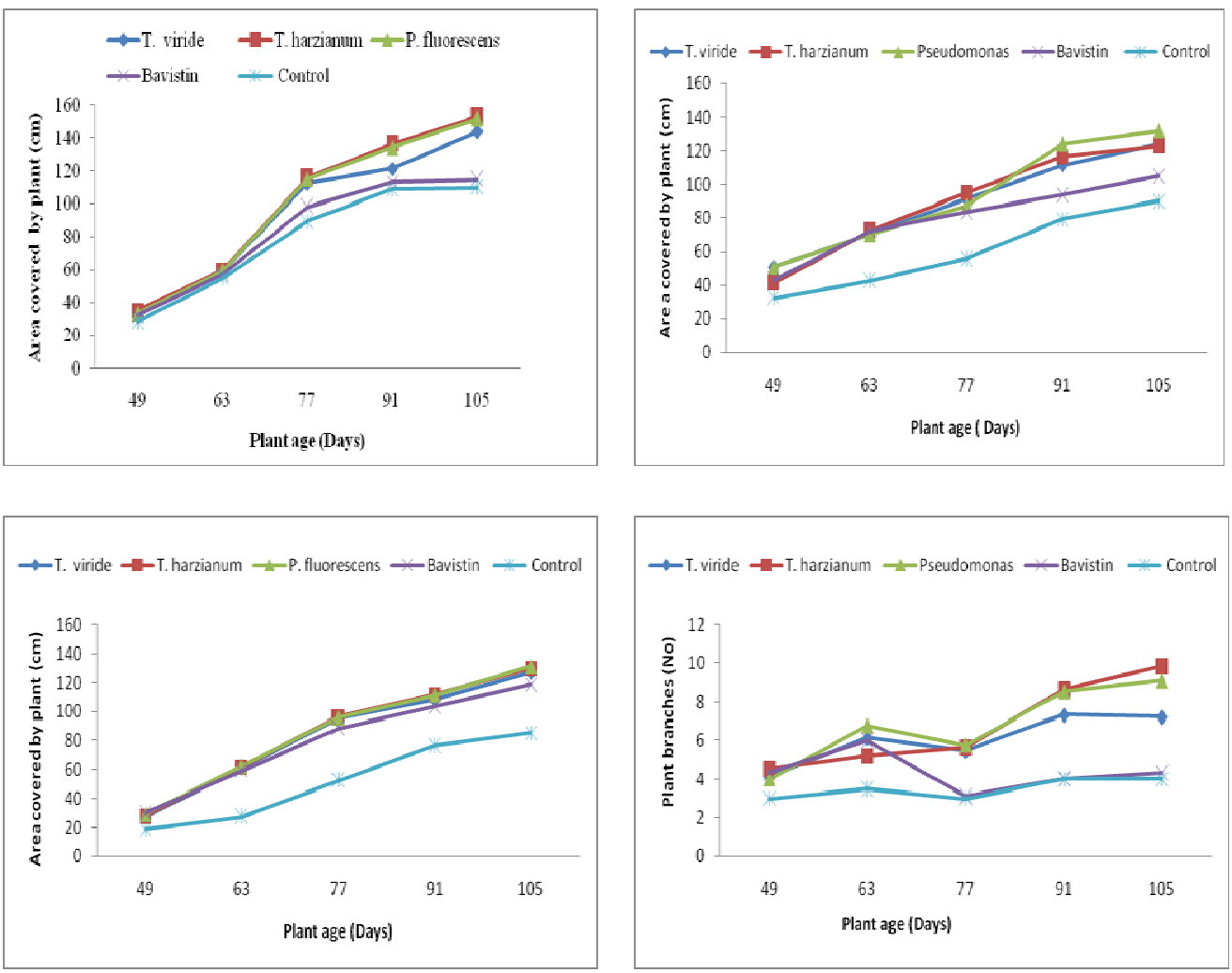

Figure 1. Area coverage by plant in different plant stage in spring and summer season Dalila and Shrijana tomato ( $A=$ Dalila spring, $B=$ Dalila Summer, $C=$ Shrijana Spring, $D=$ Shrijana Summer )

Antagonists belonging to the genus Trichoderma are among the most commonly isolated soil fungi. Due to their ability to protect plants and contain pathogen populations under different soil conditions, these fungi have been widely studied and commercially marketed as bio-pesticides, bio-fertilizers and soil amendments (Francesco et al.,2008).

The colonization of the root system by rhizosphere competent strains of Trichoderma results in increased development of root / or aerial systems and crop yields (Harmen and Kubicek, 1998). Recent research indicates that corn whose roots are colonized by Trichoderma strain $\mathrm{T}-22$ require about $40 \%$ less nitrogen fertilizer than corn whose roots lack the fungus (Howell et al., 2000).

Seed germination percentage, root length, shoot length, fresh weight, dry weight and vigor index were significantly increased by $T$. viride and P. fluroescens. T.viride inoculated cotton plants increased 2.7 and 2.4 fold, where as P. fluorescens increased 2 and 1.8 fold 
for shoot and root length respectively(Shanmugaiah et al, 2009). We clearly understands that bio-fungicide treated seed have longer root length as compare to chemical fungicide treated seeds. The observation results were found as similar which other researchers found.

Trichoderma species exert beneficial effect on plant growth and development (Harman, et al., 2004). Trichoderma strains can act colonizing the soil and/or parts of the plant, occupying the physical space avoiding the multiplication of pathogens, producing cell wall degrading enzymes against the pathogens, producing antibiotics that can kill the pathogens, promoting the plant development and inducing the defense mechanisms of the plant (Monte and Llobell, 2003). Trichoderma bio-control strains have evolved numerous mechanisms for both attacking other fungi and enhancing plant and root growth (Harman, 2000). Damping off caused by Pythium indicum in tomato seedlings had found good control by using Trichoderma viride, T. harzianum and Laetisaria arvalis (Krishnamoorthy and Bhaskaran, 1990). Application of plant based formulation of Trichoderma harzianum to nursery beds of egg plants was found effective in producing vigorous seedlings (plant height and seedling weight) with least root galling (Rao et al, 1998). Rhizobacteria-Azosperillum sp., Azotobacter chroococcum and Pseudomonas fluorescens found useful in improving emergence of tomato and reducing the damping off of tomato caused by Rhizoctonia solani (Gupta el al, 1995).

According to our study as well as other studies done by scientists, the application of biocontrol fungicide effectively control the damping off disease in tomato rather than the chemical pesticide. Because due to the various characters like soil colonization, physical space occupying and competition in food, antibiotics and enzymes produce against pathogens and promoting the plant development may be the aggregate result in less damping off in Trichoderma applied plot. Similarly, Pseudomonas fluoresecns have found useful in improving emergence of tomato and reducing the damping off of tomato.

\section{TREATMENT EFFECT ON DISEASE PREVELANCE ON FIIELD}

Damping off, late blight, mosaic virus, wilt and nematode are major disease in this location in spring and summer crop of tomato. Farmers when observed wilt, late blight and mosaic virus in their filed, they recorded in both location in both seasons. Positive sign indicates prevalence of the diseases in the field. 
Table 5. Disease status in spring and summer season in Dalila tomato at Bhaktapur district.

\begin{tabular}{|l|l|l|l|l|l|l|l|l|l|}
\hline \multirow{2}{*}{ Treatments } & \multicolumn{4}{c|}{ Spring season } & \multicolumn{5}{c|}{ Summer Season } \\
\cline { 2 - 10 } & FW & BW & LB & MV & FW & BW & LB & MV \\
\hline T. viride & & + & + & + & & + & + & + \\
\hline T. harzianum & & & + & + & & + & + & + \\
\hline P. fluorescens & & & + & + & & & + & + \\
\hline Bavistin & & + & ++ & + & & + & ++ & + \\
\hline Control & ++ & +++ & +++ & ++ & + & ++ & +++ & ++ \\
\hline
\end{tabular}

$\mathrm{FW}=$ Fusarium wilt, $\mathrm{BW}=$ Bacterial wilt, $\mathrm{LB}=\mathrm{Late}$ blight, $\mathrm{MV}=$ Mosaic virus

Table 6. Disease status in spring and summer season Shrijana tomato at Bhaktapur district.

\begin{tabular}{|l|l|l|l|l|l|l|l|l|}
\hline \multirow{2}{*}{ Treatments } & \multicolumn{4}{c|}{ Spring season } & \multicolumn{5}{c|}{ Summer Season } \\
\cline { 2 - 10 } & FW & BW & LB & MV & FW & BW & LB & MV \\
\hline T. viride & & + & + & + & & + & + & + \\
\hline T. harzianum & & & + & + & & + & + & + \\
\hline P. fluorescens & & & + & + & & & + & + \\
\hline Bavistin & & + & ++ & + & & + & ++ & + \\
\hline Control & ++ & +++ & +++ & ++ & + & ++ & +++ & ++ \\
\hline
\end{tabular}

$F W=$ Fusarium wilt, $B W=B$ acterial wilt, $L B=L$ ate blight, $M V=$ Mosaic virus

Due to the temperature, humidity, moisture of soil, the incidence and intensity of disease we found different. Bacterial wilt found slightly more in summer than in spring crop in both varieties due to high soil moisture. Similarly, late blight found more in summer crop than the spring.

\section{EFFECT OF TREATMENT ON YIELD}

The mature and ripen fruits of tomato were harvested in separate and weighted. The average yield of two varieties of tomato in spring and summer season were found as follows.

Table 7.Yield effect on two varieties of tomato in two seasons at Bhaktapur

\begin{tabular}{|l|l|l|l|l|l|l|}
\hline \multirow{2}{*}{ Treatments } & \multicolumn{2}{|c|}{ Yield of Shrijana variety (t/ha) } & \multicolumn{2}{l|}{ Yield of Dalila Variety (t/ha) } \\
\cline { 2 - 7 } & Spring & Summer & Average & Spring & Summer & Average \\
\hline T. viride & 89.51 & 87.65 & 88.58 & 101.2 & 86.21 & 93.72 \\
\hline T. harzianum & 95.68 & 90.95 & 93.31 & 116.0 & 87.04 & 101.5 \\
\hline P.fluorescens & 94.44 & 84.57 & 89.51 & 100.0 & 86.63 & 93.31 \\
\hline Bavistin & 80.86 & 71.81 & 76.34 & 64.81 & 78.39 & 71.6 \\
\hline Control & 59.26 & 52.06 & 5.566 & 53.06 & 52.47 & 52.77 \\
\hline
\end{tabular}


In Shrijana variety, we found distinct difference in yield between bio and chemical fungicide used plots. The maximum and similar yield were found from $T$. harzianum $(95.68$ $\mathrm{t} / \mathrm{ha})$ and Pseudomonas fluorescens treated plot $(94.44 \mathrm{t} / \mathrm{ha})$ followed by T. viride $(87.65$ $\mathrm{t} / \mathrm{ha}$ ) used plot in spring crop. Whereas lower yield was obtained from Bavistin used plot $(80.86 \mathrm{t} / \mathrm{ha})$. In control plot, the yield found lower ( $52.06 \mathrm{t} / \mathrm{ha}$ ) due to attack of different diseases. Similar yield trend have found in summer season tomato also. In case of Dalila variety, the yield found higher in T. harzianum treated plot (116.0 t/ha) followed by $T$. viride (101.2 t/ha) and Pseudomonas fluorescen (100.0 t/ha) in spring crop. There is higher difference in yield between Bavistin (64.81 t/ha) and bio-fungicide treated plots. The lowest yield was found from control plot $(53.06 \mathrm{t} / \mathrm{ha})$. Similar yield trend was found in summer crop in Dalila variety.

Many researchers have done the research using bio-fungicides in effective disease control. Among them some are mentioned below to support our studies.

Trichoderma species are now the most common fungal biological control agents in antagonistic action against wide range of fungal plant pathogens (Kucuk and Kivanc, 2008).

Due to the antagonistic potential in Trichoderma, the effective application of Trichoderma species as an alternative to chemical control against a wide set of fungal plant pathogens (Chet, 1987; Harman and Bjorkman, 1998). Trichoderma species are beginning to be used in reasonably large quantity in plant agriculture, both for disease control and yield increases. It is also useful for producing transgenic plants resistant to diseases and the enzymes themselves are beneficial to biological control and other processes. (Harman, 2006).

Pseudomonas fluorescens are aggressive colonizers of the rhizosphere of various crops, and have broad spectrum antagonistic activities over plant pathogens, such as antibiosis (Cartwright, et al., 1995; Rasales, et al., 1995). Some species of Pseudomonas have been recognized as antagonists of plant fungal pathogens and antibiotic producers (O'Sullivan and O'Gara, 1992).

Strains of Pseudomonas fluorescens have known biological activity against certain soilborne phytopathogenic fungi and antagonist activities against Macrophomina phaseolina, Rhizoctonia solani, Phytophthora nicotianae var.parasitica, Phythium sp. Fusarium sp. (Ahmadzadeh,et al., 2006).

The yield of tomato in spring season in both varieties found higher than in summer season. It's due to the lower incidence of late blight as well as nematode. 


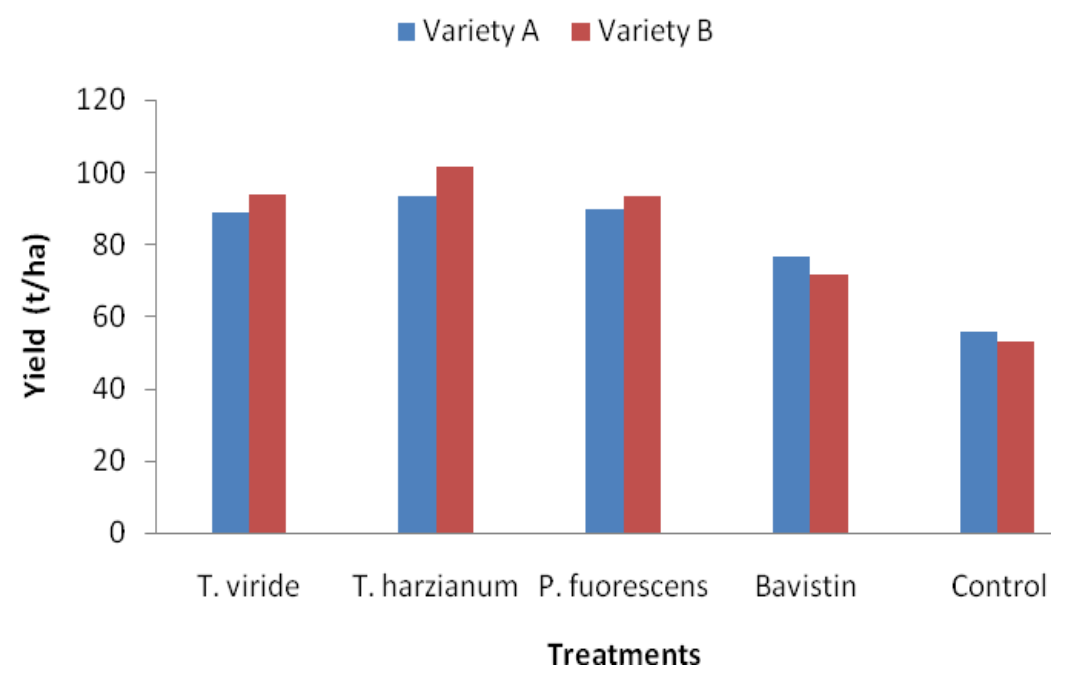

Variety $A=$ Shrijana, Variety B=Dalila

Figure 3. Yield effect in tomato after the application of bio and chemical fungicides

The yield response found higher in Shrijana variety on bio-fungicide applied plots as compared to same treatment of Dalila variety. But in Bavistin and control plot found responded higher in Dalila variety as compared to Shrijana variety due to soil characters and environment. It's may be the genetic character of the plant.

Table 8. Analysis of variance (ANOVA) table

\begin{tabular}{|l|l|l|l|l|}
\hline \multicolumn{1}{|c|}{ Sources } & $\begin{array}{c}\text { Degree of } \\
\text { Freedom }\end{array}$ & \multicolumn{1}{|c|}{$\begin{array}{c}\text { Sum of } \\
\text { squares }\end{array}$} & $\begin{array}{c}\text { Mean } \\
\text { squares }\end{array}$ & \multicolumn{1}{c|}{$\begin{array}{c}\text { Computed } \mathrm{F} \\
\text { value }\end{array}$} \\
\hline Replication & 2 & 1081.62 & 540.81 & $11.26^{* * *}$ \\
\hline Season & 1 & 8892.19 & 892.81 & $18.59^{* * *}$ \\
\hline Variety & 1 & 54.74 & 54.74 & 1.14 \\
\hline Season $\times$ Variety & 1 & 20.55 & 20.54 & 0.43 \\
\hline Treatment & 4 & 14955.74 & 3738.94 & $77.87^{*}$ \\
\hline Season $\times$ Treatment & 4 & 641.42 & 160.36 & $3.34^{*}$ \\
\hline Variety $\times$ Treatment & 4 & 363.38 & 90.84 & $1.89^{* *}$ \\
\hline Season $\times$ Variety $\times$ Treatment & 4 & 978.18 & 244.55 & $5.09^{* *}$ \\
\hline Error & 38 & 1824.59 & 48.02 & \\
\hline Total & 59 & 20813.05 & & \\
\hline
\end{tabular}


Average of three replications CV $=8.49 \%^{* * *}=$ Very highly significance at $5 \%$ level ${ }^{* *}=$ High significance at $\% 1 \%$ level ${ }^{*}=$ Significance at $5 \%$ level NS= non significance

Replication and season found very highly significance. Variety and season as well as season, variety and season found high significant. Treatment and variety and treatment found significance. But variety and season cannot found any significance.

Interaction effect of seasons and treatments on yield (t/ha)

\begin{tabular}{lll}
\hline Season & Season & \\
Treatment & Spring & Summer \\
\hline T. viride & $95.37 \mathrm{~b}$ & $86.93 \mathrm{c}$ \\
T. harzianum & $105.86 \mathrm{a}$ & $88.99 \mathrm{bc}$ \\
P.fluorescens & $97.22 \mathrm{~b}$ & $85.59 \mathrm{c}$ \\
Bevistin & $72.84 \mathrm{~d}$ & $75.1 \mathrm{~d}$ \\
Control & $56.16 \mathrm{e}$ & $52.26 \mathrm{c}$ \\
F test & Significant & \\
LSD & 8.005 & \\
\hline
\end{tabular}

Interaction effect of seasons, varieties and treatments on yield (t/ha)

\begin{tabular}{llccc}
\hline \multicolumn{1}{c}{ Season } & \multicolumn{2}{c}{ Spring } & \multicolumn{2}{c}{ Summer } \\
\multicolumn{1}{c}{ Treatment } & \multicolumn{1}{c}{ Dalila } & Shrijana & Dalila & Shrijana \\
T.viride & $101.22 \mathrm{ab}$ & $89.51 \mathrm{bc}$ & $86.20 \mathrm{bcd}$ & $87.66 \mathrm{bcd}$ \\
T.harzianum & $116.05 \mathrm{a}$ & $95.68 \mathrm{bc}$ & $87.03 \mathrm{bcd}$ & $90.94 \mathrm{bc}$ \\
P.fluorescens & $100.00 \mathrm{a}$ & $94.44 \mathrm{bc}$ & $86 . .62 \mathrm{bcd}$ & $84.67 \mathrm{bcd}$ \\
Bavistin & $64.81 \mathrm{efg}$ & $80.87 \mathrm{cde}$ & $78.39 \mathrm{bcd}$ & $71.81 \mathrm{def}$ \\
Control & 52.05 & 59.26 & 52.47 & 52.06 \\
F test & Highly Significant & & \\
LSD & 15.06 & & \\
Season, variety and treatment were analyzed and these results were found.
\end{tabular}


Table 9. Main effect on season, variety and treatments of tomato yield (t/ha)

\begin{tabular}{lll}
\hline Factors & Level & Yield $(\mathrm{t} / \mathrm{ha})$ \\
\hline Season (Factor A) & Spring & 85.492 \\
& Summer & 77.777 \\
& F test & $4 . *$ \\
& LSD & 4.76 \\
\hline Variety (Factor B) & Dalila & 82.589 \\
& Shrijana & 80.679 \\
& F test & NS \\
& LSD & - \\
\hline Treatment(Factor C) & T. viride & 91.152 \\
& T. harzianum & 97.427 \\
& Pseudomonas & 91.41 \\
& Bavistin & 73.97 \\
& Control & 54.212 \\
& F test & NS \\
& LSD & 7.530 \\
& SEm \pm & 1.265 \\
& CV & 8.49 \\
\hline
\end{tabular}

$\overline{* * *}=$ very highly significance NS=Non significance

Table 8. Economics of bio and chemical fungicide application for the control of damping off and late blight in Dalila variety tomato at Bhaktapur

\begin{tabular}{|c|c|c|c|c|c|c|c|c|c|c|}
\hline \multirow{2}{*}{ Treatments } & \multirow{2}{*}{$\begin{array}{l}\text { Yield } \\
\text { (t/ha ) }\end{array}$} & \multicolumn{2}{|c|}{$\begin{array}{l}\text { Deviation } \\
\text { from the } \\
\text { control }\end{array}$} & \multicolumn{3}{|c|}{$\begin{array}{c}\text { Cost of seed and seedling } \\
\text { treatment and two } \\
\text { sprayings }\end{array}$} & \multirow{2}{*}{$\begin{array}{c}\text { Fixed } \\
\text { cost } \\
\text { (NRs) }\end{array}$} & \multirow{2}{*}{$\begin{array}{c}\text { Total } \\
\text { cost } \\
\text { (NRs) }\end{array}$} & \multirow{2}{*}{$\begin{array}{c}\text { Net } \\
\text { profit } \\
\text { (NRs) }\end{array}$} & \multirow{2}{*}{$\begin{array}{c}\text { Benefit } \\
\text { cost } \\
\text { ratio }\end{array}$} \\
\hline & & $\begin{array}{l}\text { Yield } \\
\text { (t/ha) }\end{array}$ & $\begin{array}{l}\text { Value } \\
\text { (NRs) }\end{array}$ & Chemicals & Labor & Total & & & & \\
\hline T.viride & 93.72 & 40.95 & 3280.2 & 2.25 & 25.0 & 32.25 & 60.0 & 87.25 & 3192.95 & 37.59 \\
\hline T. harzianum & 101.5 & 48.73 & 3552.5 & 2.25 & 25.0 & 32.25 & 60.0 & 87.25 & 3465.25 & 40.71 \\
\hline P fluorescens & 93.31 & 40.54 & 3265.8 & 2.25 & 25.0 & 32.25 & 60.0 & 87.25 & 3178.55 & 37.43 \\
\hline Bavistin & 71.6 & 18.83 & 2506.0 & 1.75 & 25.0 & 31.75 & 60.0 & 86.75 & 2419.25 & 28.88 \\
\hline Control & 52.77 & - & 847.0 & - & 25.0 & 30.0 & 60.0 & 85.0 & 1762.0 & 21.72 \\
\hline Mean & 82.58 & & & & & & & & & \\
\hline SEm \pm & 1.265 & & & & & & & & & \\
\hline LSD 0.05 & 7.530 & & & & & & & & & \\
\hline $\mathrm{CV}(\%)$ & 8.49 & & & & & & & & & \\
\hline
\end{tabular}

Benefit cost ratio of Dalila variety was analysed and found highest in T. harzianum (40.71) used plots followed by T.viride (37.59) and P. fluorescens (37.43). Bavistin found lower (28.88) than other bio-agents and control found the lowest (21.72) benefit cost ratio. But according to the theme of benefit cost ratio, we found all these treatments were economically viable. 
Table 9. Economics of bio and chemical fungicide application for the control of damping off and late blight in Shrijana variety tomato at Bhaktapur

\begin{tabular}{|c|c|c|c|c|c|c|c|c|c|c|}
\hline \multirow{2}{*}{ Treatments } & \multirow{2}{*}{$\begin{array}{l}\text { Yield } \\
\text { (t/ha ) }\end{array}$} & \multicolumn{2}{|c|}{$\begin{array}{c}\text { Deviation } \\
\text { from the } \\
\text { control }\end{array}$} & \multicolumn{3}{|c|}{$\begin{array}{c}\text { Cost of seed and seedling } \\
\text { treatment and two } \\
\text { sprayings }\end{array}$} & \multirow{2}{*}{$\begin{array}{l}\text { Fixed } \\
\text { cost } \\
\text { (NRs) }\end{array}$} & \multirow{2}{*}{$\begin{array}{l}\text { Total } \\
\text { cost } \\
\text { (NRs) }\end{array}$} & \multirow{2}{*}{$\begin{array}{l}\text { Net } \\
\text { profit } \\
\text { (NRs) }\end{array}$} & \multirow{2}{*}{$\begin{array}{l}\text { Benefit } \\
\text { cost } \\
\text { ratio }\end{array}$} \\
\hline & & $\begin{array}{l}\text { Yield } \\
\text { (t/ha) }\end{array}$ & $\begin{array}{l}\text { Value } \\
\text { (NRs) }\end{array}$ & Chemicals & Labor & Total & & & & \\
\hline T.viride & 88.58 & 35.43 & 3543.2 & 2.25 & 25.0 & 32.25 & 60.0 & 87.25 & 3950.95 & 40.61 \\
\hline T. harzianum & 93.31 & 37.65 & 3732.4 & 2.25 & 25.0 & 32.25 & 60.0 & 87.25 & 4140.15 & 42.77 \\
\hline $\mathrm{P}$ fluorescens & 89.51 & 33.85 & 3580.4 & 2.25 & 25.0 & 32.25 & 60.0 & 87.25 & 3988.15 & 41.03 \\
\hline Bavistin & 76.34 & 20.68 & 3054.0 & 1.75 & 25.0 & 31.75 & 60.0 & 86.75 & 3461.75 & 35.2 \\
\hline Control & 55.66 & - & 2226.4 & - & 25.0 & 30.0 & 60.0 & 85.0 & 2636.40 & 26.19 \\
\hline Mean & 80.68 & & & & & & & & & \\
\hline SEm \pm & 1.265 & & & & & & & & & \\
\hline LSD 0.05 & 7.530 & & & & & & & & & \\
\hline $\mathrm{CV}(\%)$ & 8.49 & & & & & & & & & \\
\hline
\end{tabular}

The benefit cost ratio of Shrijana variety found higher in T. harzianum (42.77) followed by P. fluorescens (41.03). Bavistin found lower benefit cost ratio (35.2) as compare other bioagents but higher than the control (26.19). Benefit cost ratio is the ratio of gross return to the cost of cultivation which can also be expressed as returns per rupee invested. Any value greater than 2 is considered safe to the farmers from every rupee invested (Ready and Ready, 2002). On the other hand, a minimum B: C ratio of 1.5 for agricultural sector has been fixed for any enterprises to be economically viable (Bhandari, 2003).

\section{CONCLUSION}

It can be concluded and recommended that the application of T. harzianum for the control of damping off disease in Shrijana variety found highest yield followed by P. fluorescens and Bavistin as compared to Dalila variety. But time of application, $\mathrm{pH}$, texture, moisture, suitable condition for parasitism affected the efficacy of bio-control agents (Spadaro and Gullino, 2005; Inam-Ul-Haq,et al.2009). In disease control by Trichoderma spp. sandy clay loam soil gave better Fusarium contol than clay loam (Spadaro and Gullino, 2005). Trichoderma favour acidic soil (Chet and Baker, 1981; Papavizas, 1985)and nutritional conditions (Kucuk and Kivanc, 2008). Pseudomonas has evaluated promising bio-contol agents (Van Loon et al 1998; Lemanceau, 1993). Wahid (2006) found that using bio-control agents in combinations givebetter results than use of single only.

\section{Acknowledgements}

The financial support for this work was provided by National Agricultural Research and Development fund (NARDF) and the program was completed by joint effort of The IPM Trainers' Association, Nepal (TITAN), District Agriculture Development Office and District 
Integrated Pest Management Committee of Bhaktapur. We are grateful to NARDF for financial support and Entomology Division of Nepal Agricultural Research Council for technical backstopping in project completion.

\section{References}

Ahmadzadeh, M., Afsharmanesh, H., Javan-Nikkahah, M., and Sharifi-Tehrani, A. 2006. Identification of some molecular trait in fluorescent Pseudomonas with antifungal activity. Iranian Journal of Biotechnology. 4:245-253.

Bhandari, A. S. 1993. Sustainability measures of rice wheat system across agro ecological regions of Nepal. Doctoral Dissertation, Central Luzon University, Munoz, Philippines. 248 pp

Cartwright, D.K.,Chilton, W.S.,Bensom, D.M., 1995. Pyrrolnitrin and phenagin production by Pseudomonas cepacia strain $5.5 \mathrm{~B}$, a biological agent of Rhizoctonia solani. Appl. Microbiol. Biotechnol. 43: 211-221.

Chet,I. 1987.Trichoderma- application, mode of action and potential bio-control agent of soil- borne plant pathogenic fungi. In: Chet,I.(ed). Innovative Approaches to Plant Disease Control. John Wiley, New York. Pp137-160.

Chet, I. and Baker, R. 1981. Isolation and bio-control potential of Hamatum from soil naturally suppressive to Rhizoctonia solani. Phytopathology. 71: 286-290.

Deising, H.B.,Helmann, S., and Pascholati,S.F . 2008. Mechnisms and significance of fungicide resistance. Braz. Jour. Microbiol. 39(2): 386-285.

Forcelini, C.A., Goellner,C.I. and May-De Mio L.L.2001. Resistancia de fungos a fungicidas. Rev. Annu. Pathol. Planstas. 9:339-381.

Francesco Vinalea, Krishnapillai Sivasithamparamb, Emilio L. Ghisalbertic, Roberta Marraa, Sheridan L. Wooa, Matteo Lorito.2008. Trichoderma-plant-pathogen interactions. Soil Biology and Biochemistry. Elsevier. Vol 40 (1):1-10.

Gupta, V.K. and Paul,Y.S. 2001 Fungal diseases of tomato, chilli and brinjal. In: Gupta, V.K. and Paul,Y.S. (eds). Diseases of vegetable crops. Kalyani Publishers, Ludhiyana, India. pp 87-105.

Harman, G.E. 2000. Myths and dog mass of bio-control. Plant Disease. 84:377-393.

Harman, G.E., and Bjorkman, T. 1998. Potential and existing use of Trichoderma and Glocladium for plant disease control and plant growth enhancement. In: Kubicek,C.P. and Harman, G.E. (eds). Trichoderma and Gliocladium vol.2, Tylor and Francis, London. pp 1-393.

Harman,G.E. 2006. Overview of mechanisms and uses of Trichoderma spp. Phytopathology. 96:190194.

Harman, G.E., and Kubicek, P.K. 1998. Trichoderma and Gliocladium Vol. 2 Enzymes, biological control and commercial applications. Tylor and Francis, London. pp 229-265.

Harman,G.E.,Charles, R.H.,Charles, R.H., Viterbo, A.,Chet,I. and Lorito. 2004. Trichoderma speciesopportunistic virulent plant symbionts. Nature review.Vol.2 Jan.

Howell,C. R. Hanson, L. E. Stipanovic, R. D., and Puckhaber, L. S. 2000. Induction of terpenoid synthesis in cotton roots and control of Rhizoctonia solani by seed treatment with Trichoderma virens. Phytopathology 90:248-252. 
Inam-Ul-Haq,M,Javed,N, Khan,M.A.,Jaskani,M.J. Khan,M.M., Khan, H.U, Irshad, G. and Gowen,S.R. 2009. Role of temperature, moisture and Trichoderma species on the surviable of Fusarium oxysporum ciceri in the rainfed areas of Pakistan. Pak. Jour. of Bot. 41(4): 19965 -1974.

Krishnamoorthy, A.S., and Bhaskaran, R. 1990. Biological control of damping off disease of tomato caused by Pythium indicum . Journal of Biological control 4:52-54.

Kucuk, C., and Kivanc, M. 2008. Mycoparasitism in the biological control of Gibberella zeae and Asperzillus astus by Trichoderma harzianum strains. Jour. of Agriculture Technolo. 4:49-55.

Lemanceau, P. Bakker,PAHM. De Kogel,W.J. Alabouvette,C. Schippers, B.1993. Antagonastic effect of non-parasitic pathogenic Oxysporum Fo47 and Pseudobactin 358 upon Fusarium oxysporum f.sp. dianthi. Applied Environ. Microbiology. 59:73-82.

Monte, E. and Llobell, A. 2003.Trichoderma in organic agriculture. Processdings V World Avocado Congress (Actas V Congreso Mundial del Aguacate). Pp725-733.

O'Sullivan,D.J., and O'Gara,F. 1992.Traits of fluorescent Pseudomonas spp. involved in suppression of plant root pathogens. Microbiol. Review. 56:662-676.

Papavizas, G.C.1985. Trichoderma and Gliocladium biology, ecology and potential for bio-control Ann.Rev. of Phytopathol. 23:23-54.

Rao, M.S., Ready, P.P., and Nagesh, M. 1998. Evaluation of plant based formulation Trichoderma harzianum for the management of Meloidogyne incognita in egg plant. Nematol.medit. Banglore, India.26: 59- 62.

Rasales,A.M., Thomashow,L., Cook, R.J., and Mew, T.W. 1995. Isolation and identification of antifungal metabolites produced by rice associated antagonistic Pseudomonas spp. Phytopathology. 85:1028-1032.

Ready,T.Y and Ready, R. 2002. Principle of Agronomy. Kalyani Publisher, New Delhi pp 526.

Shama,P. 2011. Evaluation of disease contol and plant growth promotion potential of biocontrol agents on Pisum sativum and comparision of their activities with popular chemical agentcarbendazim.Jou. of Toxocol. and Environ. Health sc.vol 3(5):127-138.

Shanmugaiah, V., Balasubramanian, N. Gomathinayagam, S., Manoharan, P. T and Rajendran, A. 2009. Effect of single application of Trichoderma viride and Pseudomonas fluorescens on growth promotion in cotton plants. African Journal of Agricultural Research Vol. 4 (11), pp. 1220-1225

Spadaro, D, and Gullino, M.L.2005.Improving the efficacy of bio-control agents against soil borne pathogens. Crop Protect. 24:601-613.

Van Loon L.C. and Bakker, PAHM. Pietiese, CMU 1998. Systematic resistance induced by Rhizosphare bacteria. Annu. Review of Phytopathology. 36:453-483.

Wahid, O A A. 2006. Improving control of Fusarium wilt of leguminous plant by combined application of bio-agents. Phytopathol. Mediterr.45:231-237.

Yadidia I, Benhamou, N.,Chet, I.1999. Induction of defense responses in cucumber plants (Cucumis sativus L) by the bio-control agent Trichoderma harzianum. Appl. Environ. Microbiology. 65: 1061-1070. 